\title{
Decision Process Analysis on Project Priority Strategy: A Case Study of an ICT Design Firm
}

\author{
Vincent F. Yu, ${ }^{1}$ Catherine W. Kuo, ${ }^{2}$ and Ruey Huei Yeh ${ }^{1}$ \\ ${ }^{1}$ Department of Industrial Management, National Taiwan University of Science and Technology, No. 43, Section 4, \\ Keelung Road, Taipei 10607, Taiwan \\ ${ }^{2}$ Graduate Institute of Management, National Taiwan University of Science and Technology, No. 43, Section 4, \\ Keelung Road, Taipei 10607, Taiwan
}

Correspondence should be addressed to Catherine W. Kuo; ckworldwide66@gmail.com

Received 31 October 2013; Revised 7 January 2014; Accepted 9 January 2014; Published 5 March 2014

Academic Editor: Xiaoqiao He

Copyright (C) 2014 Vincent F. Yu et al. This is an open access article distributed under the Creative Commons Attribution License, which permits unrestricted use, distribution, and reproduction in any medium, provided the original work is properly cited.

Project priority strategy is the benchmarking of a corporate operation management strategy and in particular is used by a projectsbased research and development firm in the complex competence environment of the information and communication technology (ICT) industry. This research takes the variables of external environments and internal resources into account for a firm's market, technology, and finance assets in order to present a decision process on a project priority strategy. This empirical study also addresses the key factors of the interaction between business on a project development's supply chain: clients, the examined firm, and suppliers. The findings indicate that a profit-driven project can dominate the firm's strategic operations and management from the resourcebased view and analytic hierarchy process technique perspectives. At the same time, the analysis results contribute significant values to project decision management, which is highly recommended for small-medium enterprises conducting product/project development, project portfolio management, and strategic business management.

\section{Introduction}

A well-planned project priority strategy is a root cause that firmly affects a firm's business success. The framework of a project priority strategy is the benchmarking of corporate operation management and in particular is used by a research and development (R\&D)-based firm on technology driven solution development in the information and communication technology (ICT) industry. Project management success is due to an entire review process that evolves from the plan, its execution, and management. However, strategic planning and control is needed to integrate firms' resources and management into a so-called business on a project development's supply chain: the clients, the design firm, and the suppliers.

Several research papers have investigated project management success from the resource-based viewpoints. Firms' organizational behaviors, resources, and management influence are variables related to the success of a global product development strategy [1]. Project management is adopted as one source of a competitive advantages by firms and is highly recommended for project portfolio management and analysis [2]. Resource capacity allocation and management affect the schedule-driven project management [3], and meeting upto-date market trends and requirements is a must for firms, starting from the earliest solution design phase. The cross function cooperation between sales and R\&D (research and development) plays a significant role in the success of a new product's project development [4]. A solid partnership with suppliers helps contribute to a project's success more than any single function among buying-selling activities. The factors of suppliers' capacity, solution quality, and leadtime delivery extremely impact a firm's product design [5].

Different project management processes involve different procedures, especially for small and medium-sized enterprises [6]. This paper presents a small-medium Taiwanese Bluetooth solution designer to examine the corporate driving forces of the project priority strategy process. In addition, this case study assesses the inter-intrarelationship development 


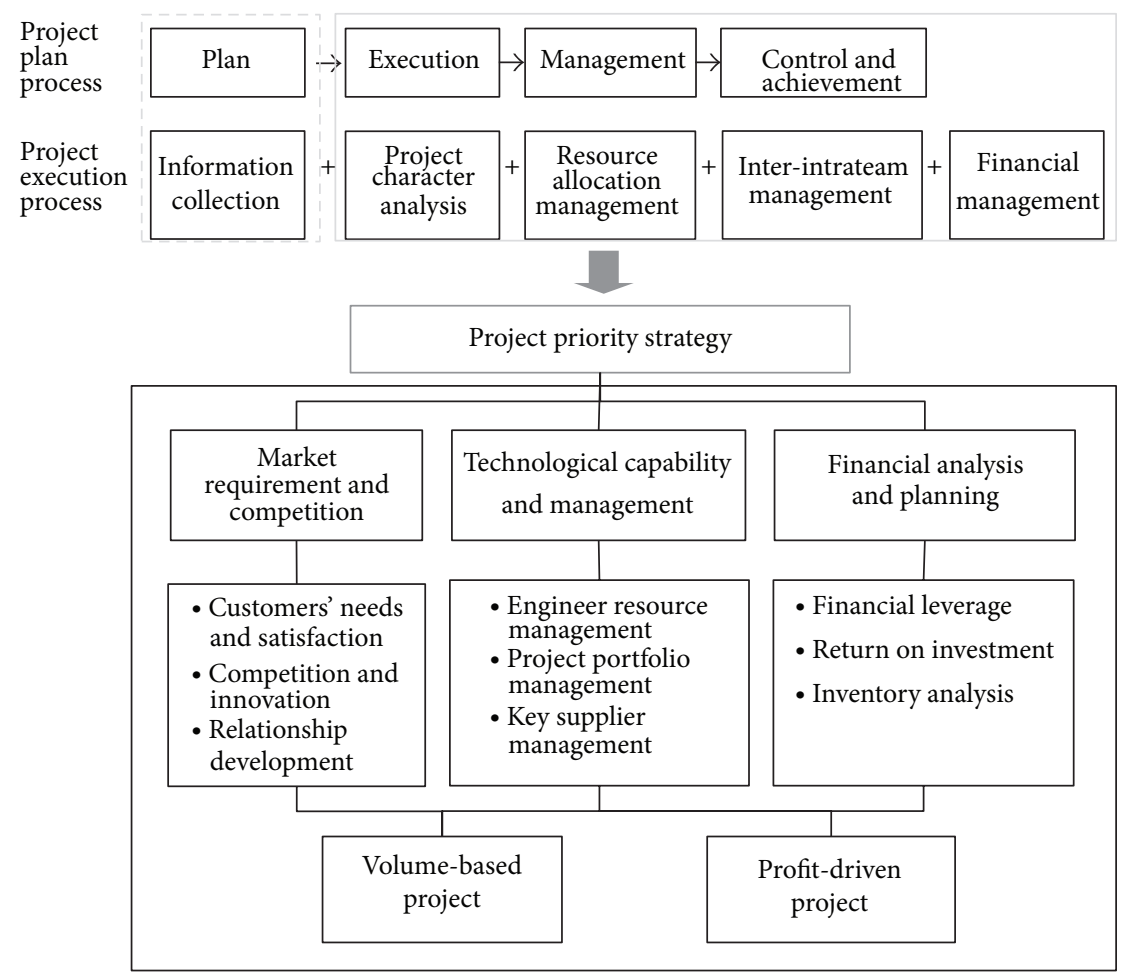

FIGURE 1: Project processes from planning and execution to project priority strategy criterion.

adopted from marketing sales and customers' feedback, management involvement in the project's progress, the capabilities of the technological resources, and the financial profits' standpoints.

Becoming the irreplaceable supplier to customers is the fundamental philosophy of enterprise operation management, but in reality a solid mechanism is needed to empower firms with the most capable deployment. The barebones of a new project involve planning, execution, management, control, and achievement that are incorporated into the phases of (i) information collection through market trend analysis and clients' requirements, (ii) project characteristics analysis for management and control, (iii) firms' resources arrangement based on capabilities and schedule concerns, (iv) inter-intrateams' cooperation due to quality and delivery control, and (v) financial planning for profit maximization. This empirical study applies the analytic hierarchy process (AHP) approach to measure the criterions from the market requirement and analysis (phase i), technological capacity and management (phases ii, iii, and iv), and financial planning and management (phase v) upon the firm's resource-based view on competencies (see Figure 1).

Section 2 reviews the academic research literature. Section 3 explores the research background and design. Section 4 presents a decision process technique, the hierarchic analysis process (AHP). Section 5 offers an empirical case study that refers to the hierarchic analysis process methodology for a decision making review. Finally, Section 6 points out the examined firm's knowledge and experience viewpoints, conclusions, and an extended research conceptual framework.

\section{Literature Review}

Several studies have been released in the academic literature to demonstrate the key factors applied to project strategy, project management, and project portfolio management from the commercial, financial, and technological viewpoints. Ernst et al. [4] review customers' functions on new product development for project progress success. Shidpour et al. [5] examine the factors of suppliers' capacity and delivery schedule and how they affect a firm's product design. Teece [7] explores firms' advantages and competences that are related to tangible and intangible assets, including technological, financial, and market resources. Ahn et al. [8] identify that commercial market assessment (i.e., market size and market growth rate) is one criterion when prioritizing and managing technological product projects. Petit [9] looks at the resources of uncertainty on the technical (i.e., technology), market (i.e., customer needs, new customers, and new markets), and financial (i.e., the ability to deliver) impacts to the management of a project portfolio under dynamic environments. Voss [10] integrates customer relationship management (CRM) to project development and presents the impacts of customer integration upon the success of project portfolio management. Chen and Wang [11] identify the competence factors on market development. Dey [12] examines project risk management under market competition 


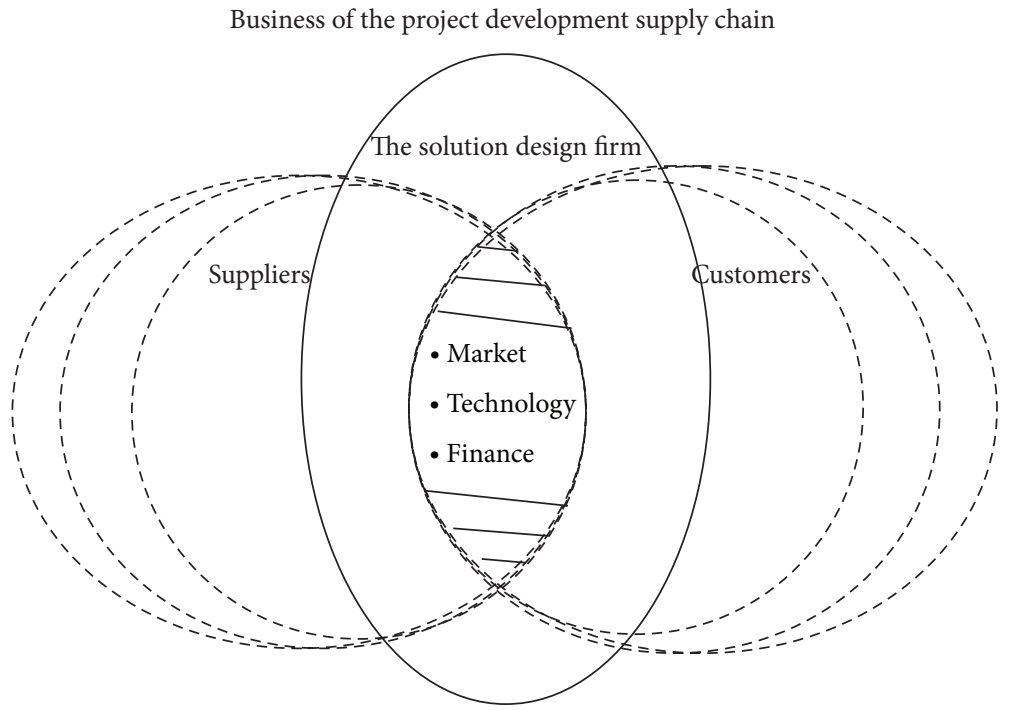

FIGURE 2: Business of the project development supply chain.

involvement. Ernst et al. [13] evaluate customer relationship and management and how they firmly relate to project performance. e Silva and Costa [14] identify interpersonality factors of human resource allocation to information system projects management and judge the personality factors on the capability for project development. Jonas [15] unveils project portfolio management tasks and execution along with management impact. Meskendahl [16] discusses a successful framework for project portfolio management within a business strategy. Nieto-Morote and Ruz-Vila [17] address how suppliers' risks from technical problems and delivery delays affect project risk assessment. Liu et al. [18] apply project risk analysis on the issue of the financial management function. Chiang and Che [19] propose the expected revenue risk as one factor to select and rank a product development project. Dey [12] analyzes the involvement of financial planning on the return on investment to project risk management. Protopappa-Sieke and Seifert [20] demonstrate that the inventory level is one critical factor for a firm's operational and financial performance.

\section{Research Background and Design}

To achieve profit maximization, firms' driving forces of competences are usually reviewed within an operation management strategy. The solution design firm examined in this study performs well through the expertise of thirty engineers and successfully releases solutions to its top two clients, which contribute $85 \%$ to the firm's total annual revenue. The firm's top management faces global competition not only on technological know-how, but also on market trend movements. (i) For new project strategy management planning, can the firm simply duplicate a strategy and perform as usual? (ii) Should the firm prioritize strategies first by volume-based business projects (for market share penetration), or by profit-driven designs (for profit maximization contribution)? (iii) Are the measurement results of the alternatives a concern simply to the design firm, or to the three parties in this business supply chain?

Our research examines an $\mathrm{R} \& \mathrm{D}$ engineering-based firm's assessments through the criterion of (i) the market requirements and analysis to be globally competitive, (ii) technological capacity and management to fulfill up-todate technological demand, and (iii) financial analysis and planning to manage financial leverage for profitability. We measure a small to medium-sized enterprise (SME)'s product project priority strategy decision and management process, by looking at the firm's resources and assets that evolve, as well as the impacts from interacting with external environments (see Figures 2 and 3).

\section{The Analytic Hierarchy Process}

The business supply chain consists of clients, the firm, and suppliers for cobusiness development. Each party has specific contributions for business success, including market requirement feedback, global relationship linkage, project portfolio management and control, and so forth. A number of research papers have unveiled research analysis through an expert group decision technique, the analytic hierarchy process (AHP), to present influences related to customers' driving points or customer satisfaction fulfillments [21, 22]. Some researchers have analyzed project development and management starting with the early stages of project screening, evaluation, or selection $[19,23,24]$, project planning $[25,26]$, project control for risk assessment [27], project risk management [12], and system development success [28]. Supplier management includes factors on supply chain quality management [29], purchase allocation management [30], strategic warehousing decision management [31], delay risks in supply from suppliers [17], and the supplier selection 


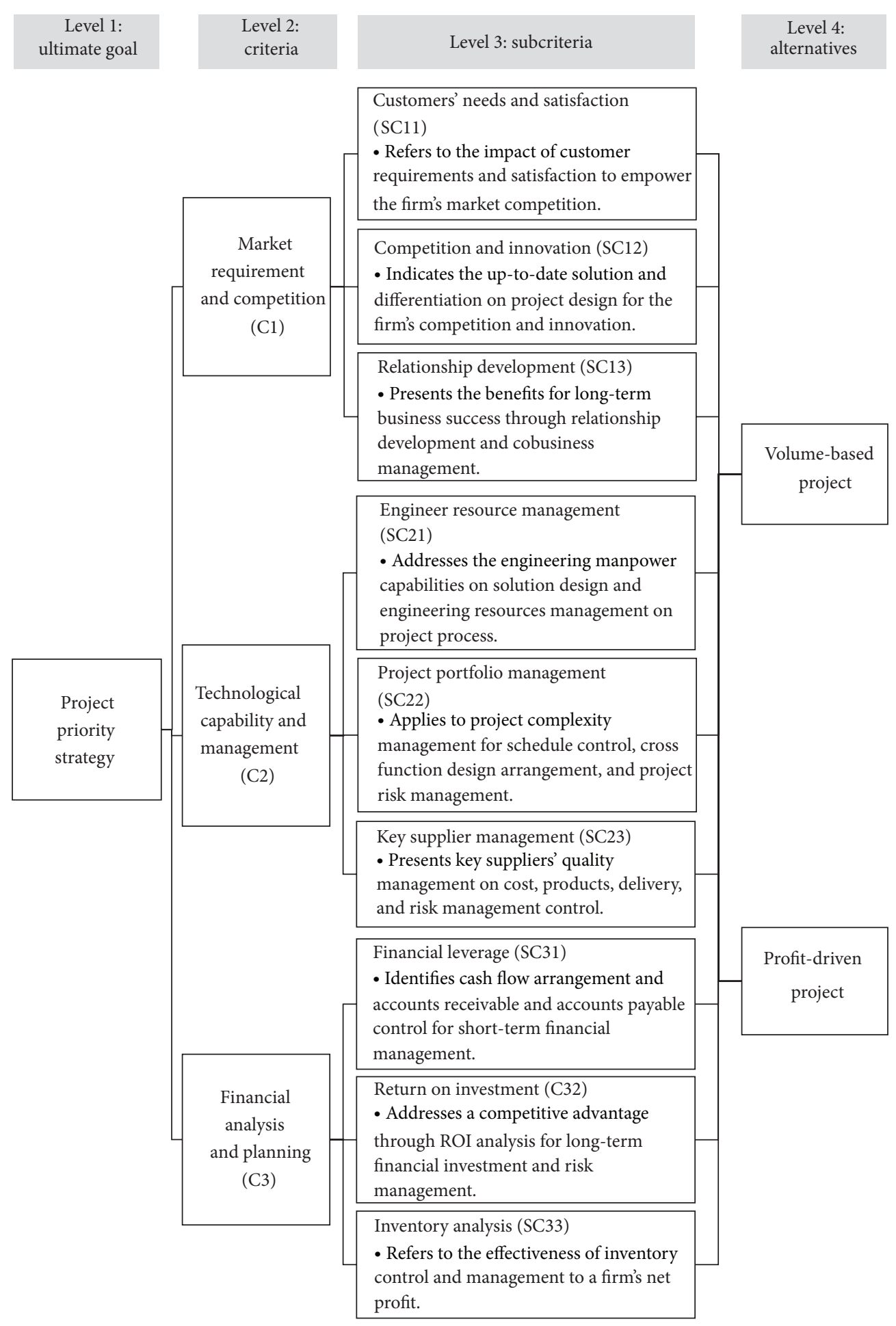

FIGURE 3: The hierarchical structure for a project priority strategy.

problem in global supply chains [32]. For business development success, the AHP has also been applied to measure competitiveness of product usage [33], an enterprise's strategies [34], competence evaluation [35], and international market development evaluation [11].
Saaty [36] develops AHP as a multiple criteria decision making tool. It has been successfully implemented as a measurement for the numeric scale of relative priorities after applying qualitative and quantitative methodologies [37]. 
(i) Establishment of a Pairwise Comparison Matrix A. An evaluation standard based on an element of the upper hierarchy arises from the pairwise comparison of each element. If this is established, then $n$ elements must give rise to $n(n-1) / 2$ elements of the pairwise comparison. Let $C_{1}, C_{2}, \ldots, C_{n}$ denote the set of elements, while $a_{i j}$ represents a quantified judgment on a pair of elements $C_{i}$, $C_{j}$. This yields an $n$-by- $n$ matrix A:

$$
\begin{aligned}
& \begin{array}{lllll}
C_{1} & C_{2} & \cdots & C_{n}
\end{array} \\
& A=\left[a_{i j}\right]=\begin{array}{c}
C_{1} \\
C_{2} \\
\vdots \\
C_{n}
\end{array}\left[\begin{array}{cccc}
1 & a_{12} & \cdots & a_{1 n} \\
\frac{1}{a_{12}} & 1 & \cdots & a_{2 n} \\
\vdots & \vdots & \ddots & \vdots \\
\frac{1}{a_{1 n}} & \frac{1}{a_{2 n}} & \cdots & 1
\end{array}\right],
\end{aligned}
$$

where $a_{i j}=1$ and $a_{i j}=1 / a_{j i}, i, j=1,2, \ldots, n$. In matrix $A$, the problem becomes one of assigning to the $n$ elements $C_{1}, C_{2}, \ldots, C_{n}$, a set of numerical weights $W_{1}, W_{2}, \ldots, W_{n}$ that reflect the recorded judgments. If $A$ is a consistency matrix, then the relations between weights $W_{i}$ and judgments $a_{i j}$ are simply given by $W_{i} / W_{j}=a_{i j}($ for $i, j=1,2, \ldots, n$.) and matrix $A$ goes as follows:

$$
A=\begin{gathered}
C_{1} \\
C_{2} \\
\vdots \\
C_{n}
\end{gathered}\left[\begin{array}{cccc}
C_{1} & C_{2} & \cdots & C_{n} \\
\frac{w_{1}}{w_{1}} & \frac{w_{1}}{w_{2}} & \cdots & \frac{w_{1}}{w_{n}} \\
\frac{w_{2}}{w_{1}} & \frac{w_{2}}{w_{2}} & \cdots & \frac{w_{2}}{w_{n}} \\
\vdots & \vdots & \ddots & \vdots \\
\frac{w_{n}}{w_{1}} & \frac{w_{n}}{w_{2}} & \cdots & \frac{w_{n}}{w_{n}}
\end{array}\right] .
$$

(ii) Eigenvalue and Eigenvector Calculation. Matrix A multiplies the element's weight vector $(x)$, which is equal to $n x$; that is, $(A-n I) x=0 ; x$ is the eigenvalue $(n)$ of the eigenvector. Because $a_{i j}$ is related to the researcher's subjective judgment, the true value $\left(W_{i} / W_{j}\right)$ has the same level of degree difference, and so $A x=n \cdot x$ cannot be set up. Saaty [37] suggests that the largest eigenvalue $\lambda_{\max }$ should be

$$
\lambda_{\max }=\sum_{j=1}^{n} a_{i j} \frac{W_{j}}{W_{i}} .
$$

If $A$ is a consistency matrix, then we can calculate eigenvector $X$ by

$$
\left(A-\lambda_{\max } I\right) X=0 .
$$

(iii) Consistency Test. The essential idea of the AHP is that a matrix $A$ of rank $n$ is only consistent if it has one positive eigenvalue $n=\lambda_{\max }$, while all other eigenvalues are zero.
Saaty further develops the consistency index (CI) to measure the deviation from a consistent matrix:

$$
\mathrm{CI}=\frac{\left(\lambda_{\max }-n\right)}{(n-1)} .
$$

We introduce the consistency ratio (CR) to aid in deciding whether to revise the matrix. It is defined as the ratio of the CI to the so-called random index (RI), which is a CI of randomly generated matrices:

$$
\mathrm{CR}=\frac{\mathrm{CI}}{\mathrm{RI}}
$$

For $n=3$, the required consistency ratio $\left(\mathrm{CR}^{\mathrm{Goal}}\right)$ should be less than 0.05 , for $n=4$ it should be less than 0.08 , and for $n \geq$ 5 it should be less than 0.10 to achieve a sufficient consistent matrix.

\section{The Case Study}

Becoming customers' irreplaceable supplier in reality means building up a solid mechanism to empower the most capability deployed for the firm. One subject that should be discussed is firms' competence evaluation [35]. Manpower availability and project schedule dependency are part of a complex project evaluation [24]. Human resource management of project team development is also a key issue that affects project success [38]. Technical knowledge availability and design quality impact project development risk [12] and the terms of supply chain payment behaviors influence a firm's financial performance [39]. For this case measurement, an AHP questionnaire survey was released to the research firm and the firm's top 2 clients in April 2013. The solution design firm $\mathrm{X}$ has a team of outstanding $\mathrm{R} \& \mathrm{D}$ engineers, focusing on Bluetooth solution design for over 8 years, and has successfully produced millions of Bluetooth devices to global markets, including stereo headsets, transmitter/receivers, portable amplified speakers, digital stereo in-ear phones and audio accessories, special headphones with a noise canceling feature, and near field communication (NFC) headphones. Client A is a well-known brand seller on the global markets. Its strong brand image covers the United States, Pan-Asia, and Europe, and the firm has especially promoted state-of-the-art Bluetooth solutions to consumers for over one decade. Client $\mathrm{B}$, an international outsourcing procurement officer (IPO) in Taiwan, has played a key role in outsourcing and reselling new ICT solutions to Japanese retail giants since 1998 and has adopted the Bluetooth series for over seven years. After initiating a cross-countries survey, we received feedback from 17 participants in 3 weeks, including 3 directors and 14 managers of the R\&D, Project Management, Sales, Purchase, and Finance departments.

An empirical case presents the product project priority strategy through the eigenvectors and weights of two alternatives under three main criteria and nine subcriteria with a global priority ratio (see Table 1). The data, from the hierarchy process analysis, indicate that the market requirement and competition ratio (C1:46.8\%) dominate the decision for project priority, followed by technological capability and 
TABLE 1: Eigenvectors and weights of two business strategies' rank under nine subcriteria.

\begin{tabular}{|c|c|c|c|c|c|c|c|}
\hline Criteria & Weights of criteria & Subcriteria & Weights of Subcriteria & $\mathrm{Ae}_{1}$ & $\mathrm{Ae}_{2}$ & Global priority & Rank \\
\hline \multirow{3}{*}{$\mathrm{Cl}$} & \multirow{3}{*}{0.468} & SC11 & 0.479 & 0.578 & 0.422 & 0.224 & 1 \\
\hline & & SC12 & 0.282 & 0.507 & 0.493 & 0.132 & 3 \\
\hline & & SC13 & 0.239 & 0.534 & 0.466 & 0.112 & 4 \\
\hline \multirow{3}{*}{$\mathrm{C} 2$} & \multirow{3}{*}{0.334} & SC21 & 0.403 & 0.407 & 0.593 & 0.135 & 2 \\
\hline & & SC22 & 0.311 & 0.333 & 0.667 & 0.104 & 5 \\
\hline & & SC23 & 0.285 & 0.508 & 0.492 & 0.095 & 6 \\
\hline \multirow{3}{*}{$\mathrm{C} 3$} & \multirow{3}{*}{0.198} & SC31 & 0.339 & 0.327 & 0.673 & 0.067 & 8 \\
\hline & & SC32 & 0.349 & 0.388 & 0.612 & 0.069 & 7 \\
\hline & & SC33 & 0.313 & 0.404 & 0.596 & 0.062 & 9 \\
\hline
\end{tabular}

TABLE 2: The overall weight to select the business strategy.

\begin{tabular}{lccc}
\hline Criteria & Weights & $\mathrm{Ae}_{1}$ & $\mathrm{Ae}_{2}$ \\
\hline $\mathrm{C} 1$ & 0.468 & 0.546 & 0.454 \\
$\mathrm{C} 2$ & 0.334 & 0.420 & 0.580 \\
$\mathrm{C} 3$ & 0.198 & 0.374 & 0.626 \\
\hline \multirow{2}{*}{ Result } & Aggregate score & $\mathbf{0 . 4 7 4}$ & $\mathbf{0 . 5 2 6}$ \\
& Rank & $\mathbf{2}$ & $\mathbf{1}$ \\
\hline
\end{tabular}

management (C2:33.4\%), and financial analysis and planning (C3:19.8\%). The weights of subcriteria on customers' needs and satisfaction (SC11: 0.479) significantly influence decision making compared with competition and innovation (SC12: 0.282) and relationship development (SC13: 0.239). At the same time, engineer resource management (SC21: 0.403) is also the first priority of concern when project portfolio management (SC22:0.311) and key supplier management (SC23: 0.285) are involved.

Based upon a global priority ranking of nine subcriteria characters, we prioritize customers' needs and satisfaction (SC11), engineer resource management (SC21), competition and innovation (SC12), relationship development (SC13), and project portfolio management (SC22) among the top five, which identifies the following. (1) The greatest impact for a firm's project priority strategy success is to achieve market requirements and customers' satisfaction. (2) The engineers' manpower capabilities on solution design and resource management on project process are the keys to project execution and control. (3) An up-to-date solution release and differentiation on new project design in fact indicate a firm's advantages on competition and innovation. (4) For a long-term business success strategy plan, relationship development and cobusiness management skills should be applied. (5) Project complexity management on scheduling control, cross function design arrangement, and project risk management should be reviewed simultaneously. From the overall weight measurement analysis, after experts' feedback the profit-driven project $(52.6 \%)$ is much more preferred compared with the $47.4 \%$ marking priority for volume-based project development (see Table 2).
5.1. Sensitivity Analysis. We apply sensitivity analysis to view the weights of various criteria for selecting the degree of influence of the alternatives for the overall study. This evaluation reveals the weight of the one main criterion used for selecting the two degrees of influence of the alternatives. The percentage ratio on the volume-based project strategy (50.1\%) is higher than profit-driven project strategy (49.9\%) when the criteria weight on "Market Requirement and Competition" increases from (a) $46.8 \%$ to (b) $66.7 \%$. (see Figure 4). When the weight of "Technological Capability Management" changes from (a) $0.1 \%$ to (b) $41.6 \%$, the priority of the original selection does not change (see Figure 5). When the weight of "Financial Analysis \& Plan" changes from (a) $0.1 \%$ to (b) $29.4 \%$, the priority of the original selection does not change (see Figure 6).

\section{Conclusions}

To bridge the gaps between the market and suppliers as applied on prioritizing project strategy and management, we have compared previous studies with our empirical analysis factors. In practice, we have assessed the impact elements of the external environments and internal resources that are inter-/intradeployed by customers, the project development firm, and the suppliers in order to comprehensively examine the data examination through qualitative and quantitative analyses (see Table 3).

Global ICT has been driven by economic, social, and environmental factors that are increasingly impacting technology innovation [40]. ICT acceptance is highlighted by 


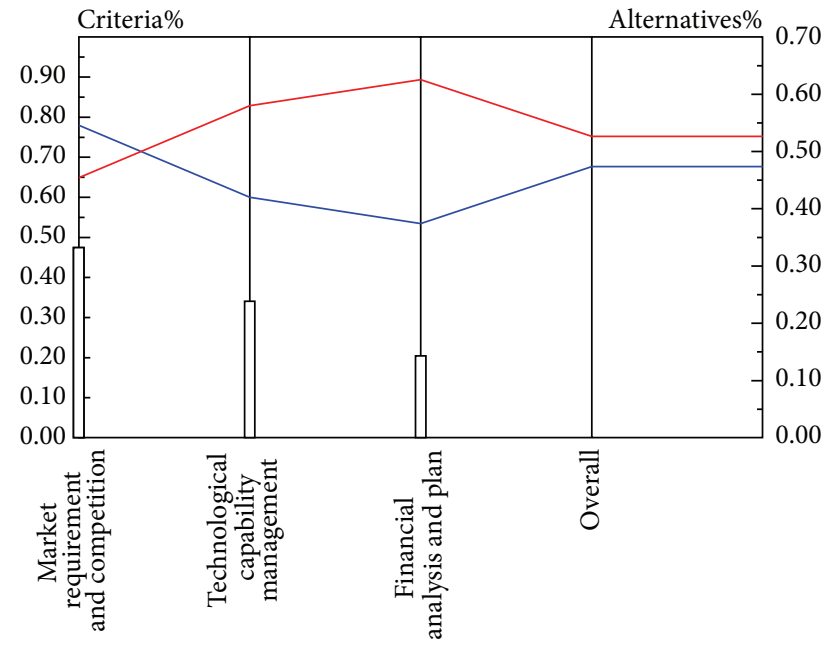

- Profit-driven

_ Volume-based

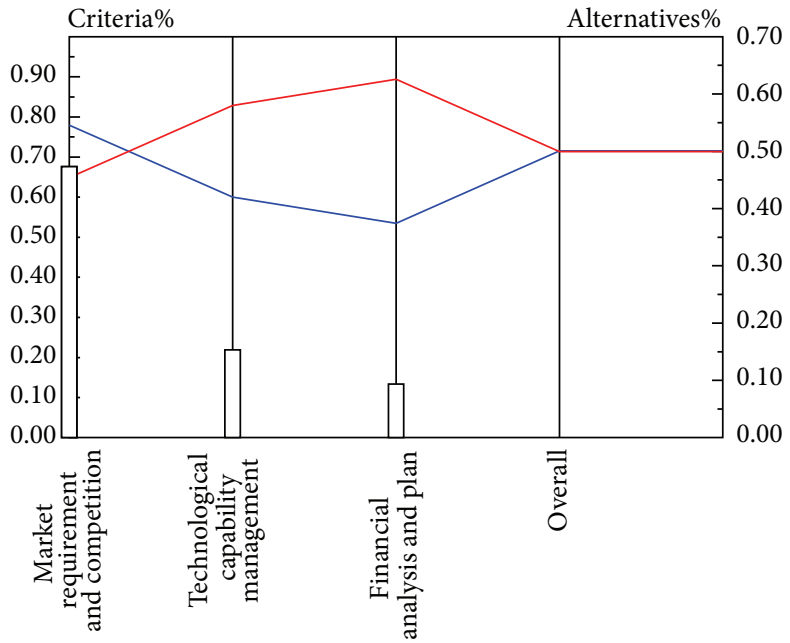

— Profit-driven

_ Volume-based

(a)

(b)

FIGURE 4: Sensitivity analysis with respect to market requirements and competition.

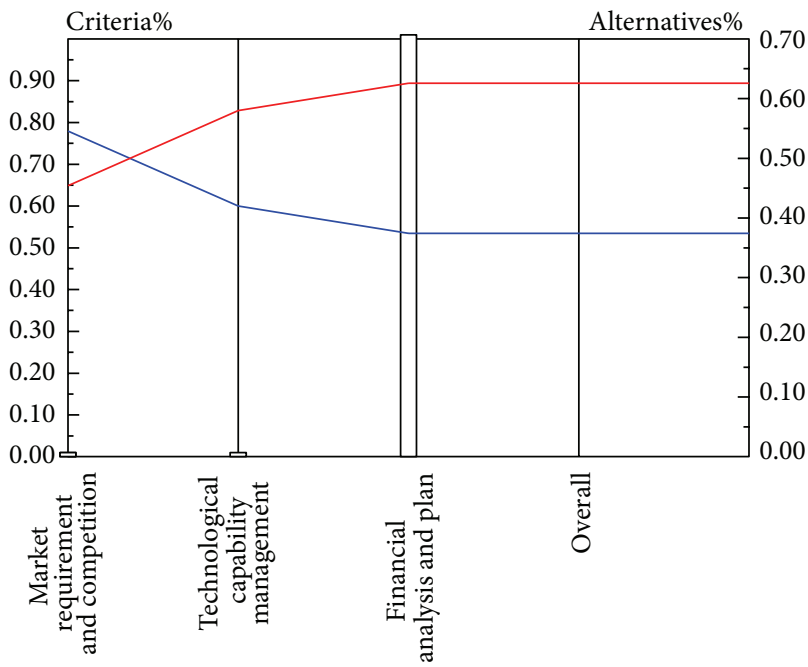

- Volume-based

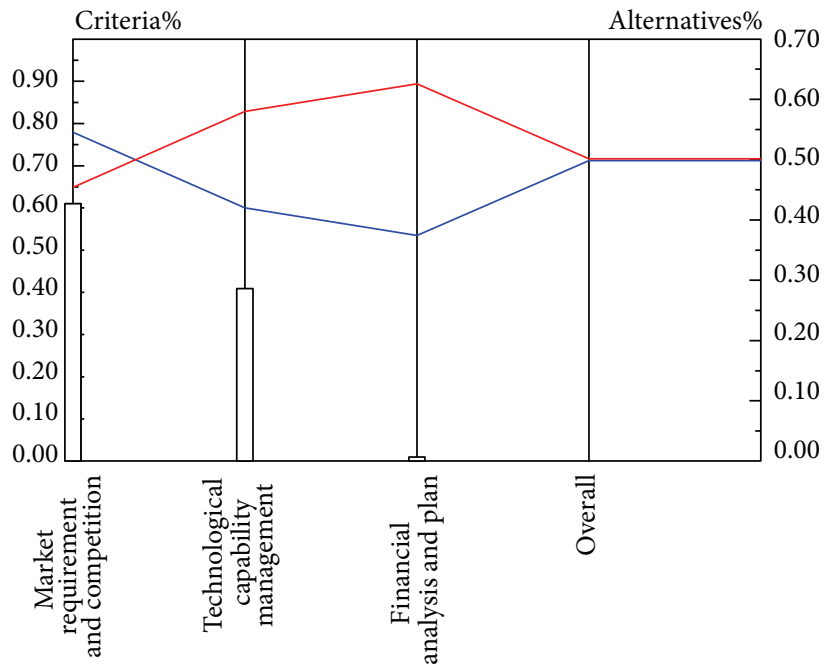

(b)
- Volume-based

(a)

FIGURE 5: Sensitivity analysis with respect to technological capability management.

key characteristics from the perspectives of policy makers, market users, and technology innovation [41]. ICT impacts competitiveness and innovation through the launch of new products/services, new processes, and technology served to communicate with people [42]. Customers might be willing to pay an extra cost and waiting time for ICT product specifications that are featured as an inquiry to a higher level of business capability and organizational support that will significantly affect ICT project performance due to teams' motivation and interaction [43]. 


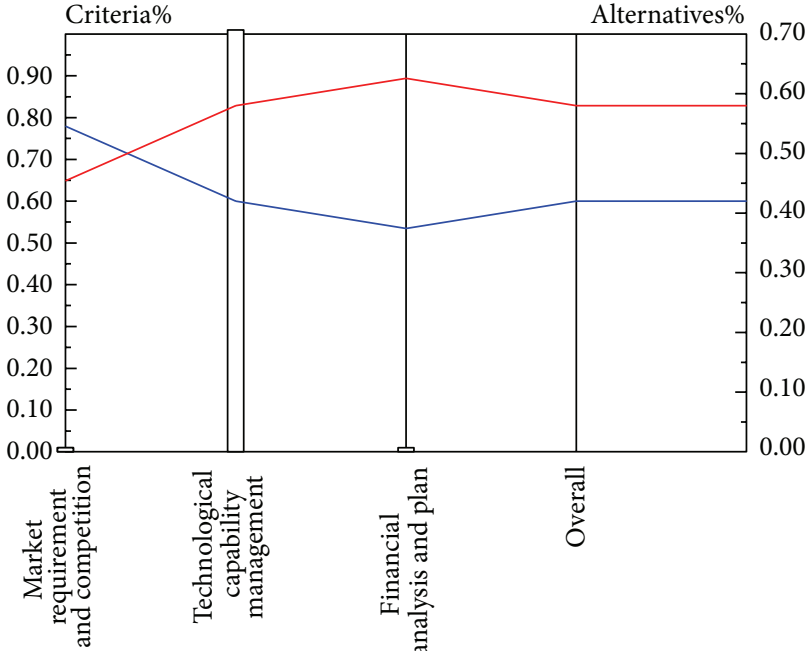

_ Profit-driven

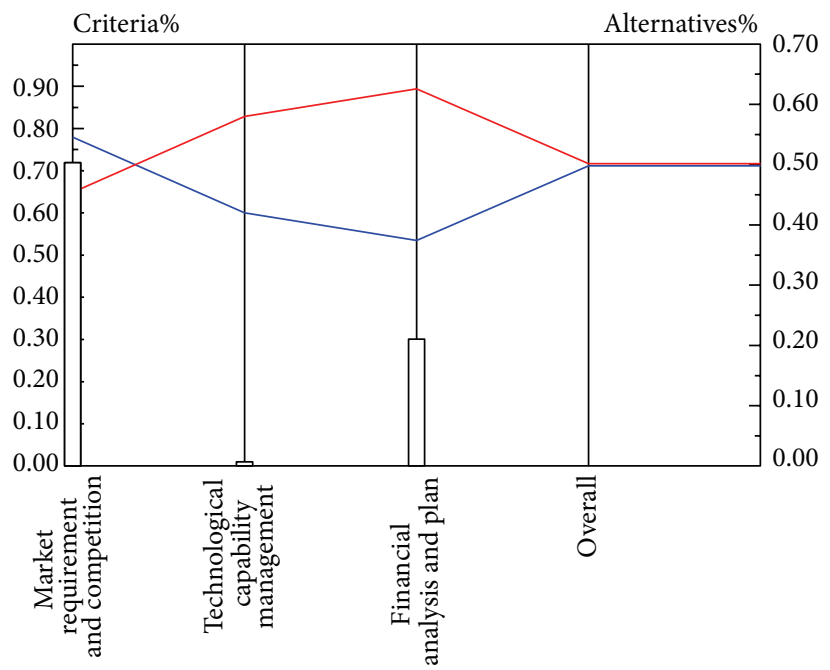

(b)
— Profit-driven
Volume-based

(a)

FIGURE 6: Sensitivity analysis with respect to financial analysis and planning.

\begin{tabular}{|l|l|l|l|}
\hline \multicolumn{1}{|c|}{ Clients } & $\begin{array}{l}\text { The solution } \\
\text { design firm }\end{array}$ & \multicolumn{1}{|c|}{ Suppliers } \\
\hline $\begin{array}{l}\text { Market } \\
\text { requirement } \\
\text { and } \\
\text { competition }\end{array}$ & $\begin{array}{l}\text { - Customers' } \\
\text { needs and market } \\
\text { trend fulfillment }\end{array}$ & $\begin{array}{l}\text { - Competition } \\
\text { and innovation } \\
\text { - Relationship } \\
\text { development }\end{array}$ & $\begin{array}{l}\text { - Long-term business } \\
\text { development }\end{array}$ \\
\hline $\begin{array}{l}\text { Technological } \\
\text { capability and } \\
\text { management }\end{array}$ & $\begin{array}{l}\text { - Codevelopment } \\
\text { and management } \\
\text { of project success }\end{array}$ & $\begin{array}{l}\text { - Resource } \\
\text { capability and } \\
\text { management } \\
\text { of PPM }\end{array}$ & $\begin{array}{l}\text { - Capacity, quality, and } \\
\text { delivery management }\end{array}$ \\
\hline $\begin{array}{l}\text { Financial } \\
\text { analysis } \\
\text { and planning }\end{array}$ & $\begin{array}{l}\text { - Payment terms } \\
\text { behavior } \\
\text { management }\end{array}$ & $\begin{array}{l}\text { investment } \\
\text { planning }\end{array}$ & $\begin{array}{l}\text { - Lead-time and } \\
\text { inventory management }\end{array}$ \\
\hline
\end{tabular}

FIGURE 7: The matrix on factor analysis.

The insights of this empirical research study are as follows. (a) The research takes the variables of external environments into account, which interact between clients/markets, the examined firm, and suppliers, and are part of the so-called business of project development supply chain. (b) We deploy significant values from the qualitative resource-based view to address a systematical framework from a firm's capabilities of knowledge and expertise drawn from technology, market, and financial leverage phases as identified on Figure 1. (c) We present the quantitative data by a matrix on factor analysis with three criteria and nine critical characters (see Figure 7). (d) Following a data analysis technique, we use the analytic hierarchy process methodology to measure and analyze the interdependent factors for the priority of alternatives. (e) Through the sensitivity analysis report, we propose that top management make further efforts at evaluating the market sensitivity for customers' needs and satisfaction concerns and build up engineering manpower resource management and the firm's capabilities at improving its competitiveness and innovation. (f) The results are highly recommended for small-medium enterprises conducting product/project development, project portfolio management, and strategic business management.

For long-term business success, this R\&D solution design firm is in fact relatively concerned about the product quality control and on-time delivery issues performed by 3rd-party outsourcing production site(s). Risk management for SMEs is critical due to the uncertainty of market requirements along with rapid technology changes. Key component suppliers (i.e., IC driver solution providers) push technical knowhow to deploy product design fulfillment. Moreover, the cost of an IC driver is usually $50 \%$ of the bill-of-materials cost of one product device. Thus, future research on this case can analyze key component suppliers' capabilities, 
TABLE 3: Characters on bridging the gaps between previous research studies and our empirical case analysis.

\begin{tabular}{|c|c|c|}
\hline Characters & Issues and findings & Research studies \\
\hline \multicolumn{3}{|c|}{ (A) Literature review on researchers' analysis } \\
\hline (i) Knowledge-based resources & $\begin{array}{l}\text { Intangible resources on project management to } \\
\text { competitive advantage }\end{array}$ & Killen et al. (2012) [2] \\
\hline $\begin{array}{l}\text { (ii) Resource capacity and } \\
\text { management }\end{array}$ & Schedule-driven project in a multi-project environment & Yaghootkar and Gil (2012) [3] \\
\hline (iii) Customers' functions and needs & $\begin{array}{l}\text { On new product development for project progress } \\
\text { success }\end{array}$ & Ernst et al. (2011) [13] \\
\hline $\begin{array}{l}\text { (iv) Strategic alignment with } \\
\text { customers }\end{array}$ & $\begin{array}{l}\text { Customer integration on project portfolio management } \\
\text { success }\end{array}$ & Voss $(2012)[10]$ \\
\hline (v) Project level risk & Project risk management on market competition & Dey $(2010)[12]$ \\
\hline (vi) Human resources allocation & $\begin{array}{l}\text { Time taken effect to information system project } \\
\text { achievement }\end{array}$ & e Silva and Costa (2013) [14] \\
\hline (vii) Project portfolio management & $\begin{array}{l}\text { Tasks and execution and management involvement to } \\
\text { PPM performance }\end{array}$ & Jonas (2010) [15] \\
\hline (viii) Financial management & $\begin{array}{l}\text { Finance leverage and management on project risk } \\
\text { factors }\end{array}$ & Liu et al. (2012) [18] \\
\hline (ix) Expected revenue risk & Developing new product development project criteria & Chiang and Che (2010) [19] \\
\hline (x) Supplier risk and management & Delays in supply and technical problems to project risk & Nieto-Morote and Ruz-Vila (2011) [17] \\
\hline $\begin{array}{l}\text { (xi) Supplier capacity and delivery } \\
\text { schedule }\end{array}$ & Effectiveness on product design project analysis & Shidpour et al. (2013) [5] \\
\hline
\end{tabular}

(B) Project priority strategy analysis factors through the aspects of external environments and internal resources

(i) Customers' needs and satisfaction

(ii) Competition and innovation

(iii) Relationship development

(iv) Engineer resource management

(v) Project portfolio management

(vi) Key supplier management

(vii) Financial leverage

(viii) Return on investment

(ix) Inventory analysis
The impact of customer requirements and satisfaction to empower the firm's market competition Up-to-date solution and differentiation on project design for the firm's competition and innovation

The benefits for long-term business success through relationship development and cobusiness management

Engineering manpower capabilities on solution design and engineering resources management on project process

Project complexity management-schedule control, cross function design arrangement, and project risk management

Key suppliers' quality management on cost, products, delivery, and risk management control

Cash flow arrangement and accounts receivable and accounts payable control for short-term financial management

Competitive advantage by return on investment analysis for long-term financial investment and risk management

The effectiveness of inventory control and management to a firm's net profit

Note: (B) Project priority strategy analysis factors: the research takes the variables of external environments and internal resources into account that interact between clients/markets, the examined firm, and suppliers, which is the so-called business of the project development supply chain.

productivities, and reliability after profit-driven projects have been implemented.

\section{Conflict of Interests}

The authors declare that there is no conflict of interests regarding the publication of this paper.

\section{Acknowledgments}

The authors thank the editors and referees for their helpful comments and suggestions. This work was partially supported by the National Science Council of the Republic of
China (Taiwan) under Grant NSC 102-2221-E-011-082-MY3. This support is gratefully acknowledged.

\section{References}

[1] U. de Brentani, E. J. Kleinschmidt, and S. Salomo, "Success in global new product development: impact of strategy and the behavioral environment of the firm," Journal of Product Innovation Management, vol. 27, no. 2, pp. 143-160, 2010.

[2] C. P. Killen, K. Jugdev, N. Drouin, and Y. Petit, "Advancing project and portfolio management research: applying strategic management theories," International Journal of Project Management, vol. 30, no. 5, pp. 525-538, 2012. 
[3] K. Yaghootkar and N. Gil, "The effects of schedule-driven project management in multi-project environments," International Journal of Project Management, vol. 30, no. 1, pp. 127-140, 2012.

[4] H. Ernst, W. D. Hoyer, and C. Rübsaamen, "Sales, marketing, and research-and-development cooperation across new product development stages: implications for success," Journal of Marketing, vol. 74, no. 5, pp. 80-92, 2010.

[5] H. Shidpour, M. Shahrokhi, and A. Bernard, "A multi-objective programming approach, integrated into the TOPSIS method, in order to optimize product design; in three-dimensional concurrent engineering," Computers \& Industrial Engineering, vol. 64, no. 4, pp. 875-885, 2013.

[6] R. Turner, A. Ledwith, and J. Kelly, "Project management in small to medium-sized enterprises: tailoring the practices to the size of company," Management Decision, vol. 50, no. 5, pp. $942-$ 957, 2012.

[7] D. J. Teece, Dynamic Capabilities and Strategic Management: Organizing for Innovation and Growth, Oxford University Press, Oxford, UK, 2009.

[8] M. J. Ahn, O. Zwikael, and R. Bednarek, "Technological invention to product innovation: a project management approach," International Journal of Project Management, vol. 28, no. 6, pp. 559-568, 2010.

[9] Y. Petit, "Project portfolios in dynamic environments: organizing for uncertainty," International Journal of Project Management, vol. 30, no. 5, pp. 539-553, 2012.

[10] M. Voss, "Impact of customer integration on project portfolio management and its success-developing a conceptual framework," International Journal of Project Management, vol. 30, no. 5, pp. 567-581, 2012.

[11] M. K. Chen and S.-C. Wang, "The critical factors of success for information service industry in developing international market: using analytic hierarchy process (AHP) approach," Expert Systems with Applications, vol. 37, no. 1, pp. 694-704, 2010.

[12] P. K. Dey, "Managing project risk using combined analytic hierarchy process and risk map," Applied Soft Computing Journal, vol. 10, no. 4, pp. 990-1000, 2010.

[13] H. Ernst, W. D. Hoyer, M. Krafft, and K. Krieger, "Customer relationship management and company performancethe mediating role of new product performance," Journal of the Academy of Marketing Science, vol. 39, no. 2, pp. 290-306, 2011.

[14] L. C. e Silva and A. P. C. S. Costa, "Decision model for allocating human resources in information system projects," International Journal of Project Management, vol. 31, no. 1, pp. 100-108, 2013.

[15] D. Jonas, "Empowering project portfolio managers: how management involvement impacts project portfolio management performance," International Journal of Project Management, vol. 28, no. 8, pp. 818-831, 2010

[16] S. Meskendahl, "The influence of business strategy on project portfolio management and its success-a conceptual framework," International Journal of Project Management, vol. 28, no. 8, pp. 807-817, 2010.

[17] A. Nieto-Morote and F. Ruz-Vila, "A fuzzy approach to construction project risk assessment," International Journal of Project Management, vol. 29, no. 2, pp. 220-231, 2011.

[18] J. Liu, Q. Li, and Y. Wang, "Risk analysis in ultra deep scientific drilling project-a fuzzy synthetic evaluation approach," International Journal of Project Management, vol. 31, no. 3, pp. 449458, 2012.
[19] T.-A. Chiang and Z. H. Che, "A fuzzy robust evaluation model for selecting and ranking NPD projects using Bayesian belief network and weight-restricted DEA," Expert Systems with Applications, vol. 37, no. 11, pp. 7408-7418, 2010.

[20] M. Protopappa-Sieke and R. W. Seifert, "Interrelating operational and financial performance measurements in inventory control," European Journal of Operational Research, vol. 204, no. 3, pp. 439-448, 2010.

[21] Y.-L. Li, J.-F. Tang, and X.-G. Luo, "An ECI-based methodology for determining the final importance ratings of customer requirements in MP product improvement," Expert Systems with Applications, vol. 37, no. 9, pp. 6240-6250, 2010.

[22] C.-L. Lin, C.-W. Chen, and G.-H. Tzeng, "Planning the development strategy for the mobile communication package based on consumers' choice preferences," Expert Systems with Applications, vol. 37, no. 7, pp. 4749-4760, 2010.

[23] M. P. Amiri, "Project selection for oil-fields development by using the AHP and fuzzy TOPSIS methods," Expert Systems with Applications, vol. 37, no. 9, pp. 6218-6224, 2010.

[24] L.-A. Vidal, F. Marle, and J.-C. Bocquet, "Using a Delphi process and the Analytic Hierarchy Process (AHP) to evaluate the complexity of projects," Expert Systems with Applications, vol. 38, no. 5, pp. 5388-5405, 2011.

[25] M. Abdelrahman, T. Zayed, and A. Elyamany, "Best-value model based on project specific characteristics," Journal of Construction Engineering and Management, vol. 134, no. 3, pp. 179-188, 2008.

[26] G. N. Angelou and A. A. Economides, "A decision analysis framework for prioritizing a portfolio of ICT infrastructure projects," IEEE Transactions on Engineering Management, vol. 55, no. 3, pp. 479-495, 2008.

[27] T. Zayed, M. Amer, and J. Pan, "Assessing risk and uncertainty inherent in Chinese highway projects using AHP," International Journal of Project Management, vol. 26, no. 4, pp. 408-419, 2008.

[28] S. Sarker, C. L. Munson, S. Sarker, and S. Chakraborty, "Assessing the relative contribution of the facets of agility to distributed systems development success: an analytic hierarchy process approach," European Journal of Information Systems, vol. 18, no. 4, pp. 285-299, 2009.

[29] C.-H. Kuei, C. N. Madu, and C. Lin, "Implementing supply chain quality management," Total Quality Management \& Business Excellence, vol. 19, no. 11, pp. 1127-1141, 2008.

[30] J.-R. Yu and C.-C. Tsai, "A decision framework for supplier rating and purchase allocation: a case in the semiconductor industry," Computers \& Industrial Engineering, vol. 55, no. 3, pp. 634-646, 2008.

[31] H. Min, "Application of a decision support system to strategic warehousing decisions," International Journal of Physical Distribution \& Logistics Management, vol. 39, no. 4, pp. 270-281, 2009.

[32] G. N. Yücenur, Ö. Vayvay, and N. Ç. Demirel, "Supplier selection problem in global supply chains by AHP and ANP approaches under fuzzy environment," The International Journal of Advanced Manufacturing Technology, vol. 56, no. 5-8, pp. 823-833, 2011.

[33] C.-C. Liu, "Measuring and prioritising value of mobile phone usage," International Journal of Mobile Communications, vol. 8, no. 1, pp. 41-52, 2010.

[34] S. Li and J. Z. Li, "Hybridising human judgment, AHP, simulation and a fuzzy expert system for strategy formulation under uncertainty," Expert Systems with Applications, vol. 36, no. 3, pp. 5557-5564, 2009. 
[35] M. Amiri, M. Zandieh, R. Soltani, and B. Vahdani, "A hybrid multi-criteria decision-making model for firms competence evaluation," Expert Systems with Applications, vol. 36, no. 10, pp. 12314-12322, 2009.

[36] T. L. Saaty, The Analytic Hierarchy Process: Planning, Priority Setting, Resources Allocation, McGraw-Hill, New York, NY, USA, 1980.

[37] T. L. Saaty, "How to make a decision: the analytic hierarchy process," European Journal of Operational Research, vol. 48, no. 1, pp. 9-26, 1990.

[38] O. Zwikael and E. Unger-Aviram, "HRM in project groups: the effect of project duration on team development effectiveness," International Journal of Project Management, vol. 28, no. 5, pp. 413-421, 2010.

[39] H. L. Chen, "An empirical examination of project contractors' supply-chain cash flow performance and owners' payment patterns," International Journal of Project Management, vol. 29, no. 5, pp. 604-614, 2011.

[40] D. M. Weber and R. J. Kauffman, "What drives global ICT adoption? Analysis and research directions," Electronic Commerce Research and Applications, vol. 10, no. 6, pp. 683-701, 2011.

[41] P. Verdegem and L. de Marez, "Rethinking determinants of ICT acceptance: towards an integrated and comprehensive overview," Technovation, vol. 31, no. 8, pp. 411-423, 2011.

[42] A. Ollo-López and M. E. Aramendía-Muneta, "ICT impact on competitiveness, innovation and environment," Telematics and Informatics, vol. 29, no. 2, pp. 204-210, 2012.

[43] R. Gelbard and A. Carmeli, "The interactive effect of team dynamics and organizational support on ICT project success," International Journal of Project Management, vol. 27, no. 5, pp. 464-470, 2009. 


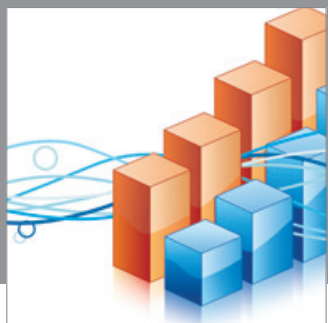

Advances in

Operations Research

mansans

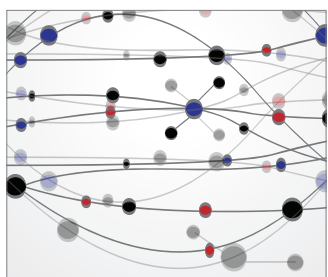

The Scientific World Journal
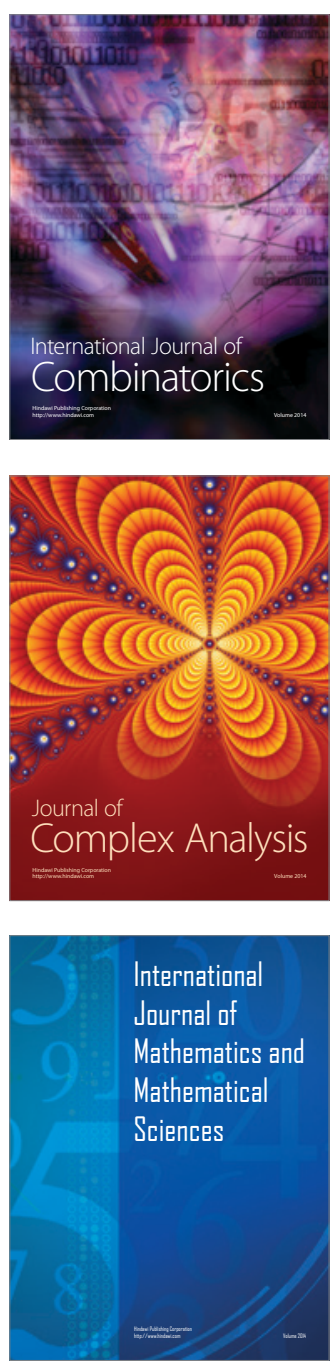
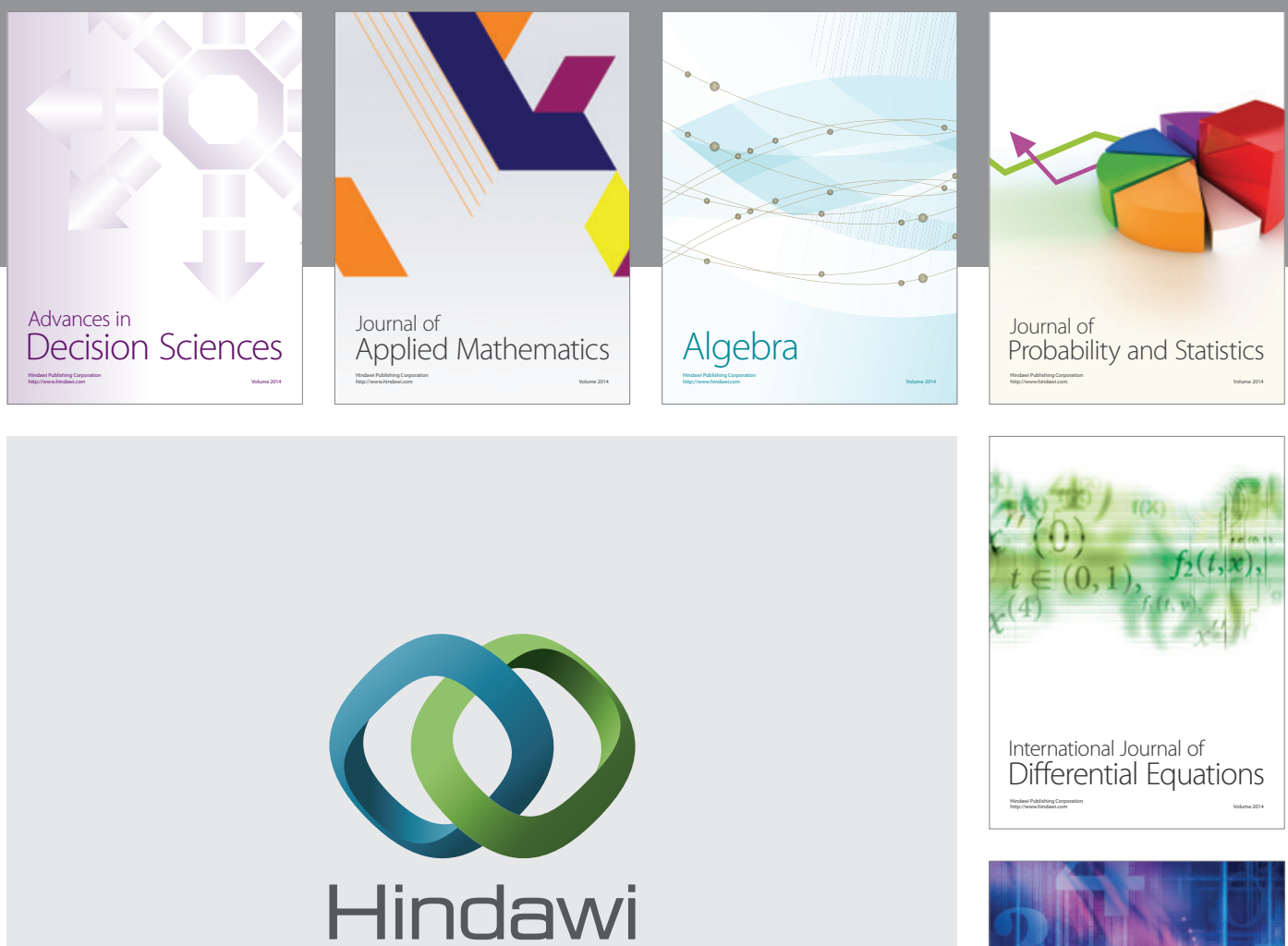

Submit your manuscripts at http://www.hindawi.com
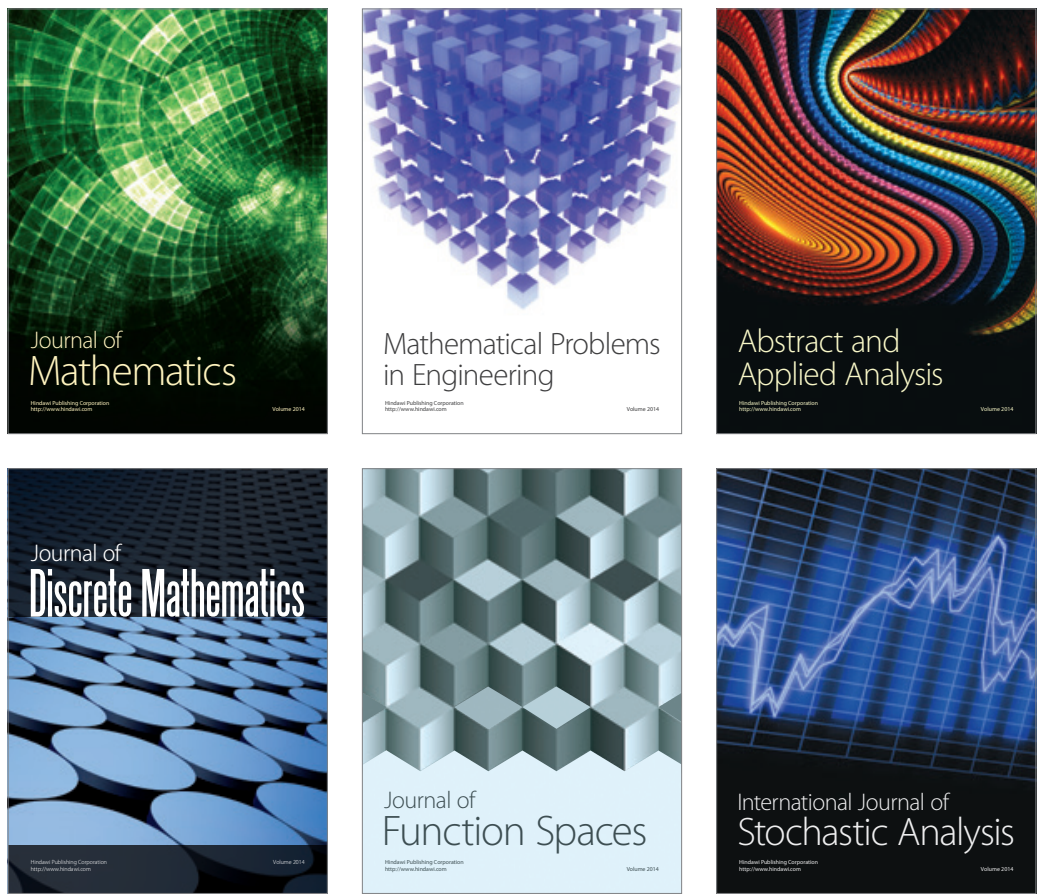

Journal of

Function Spaces

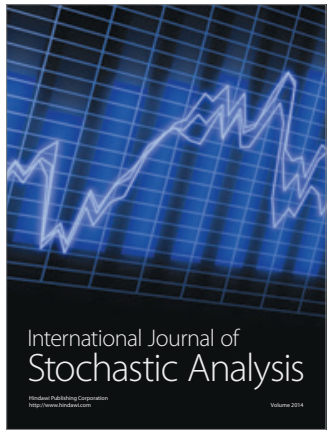

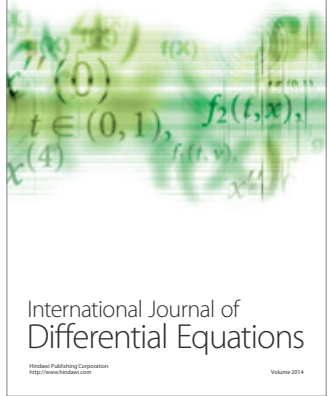
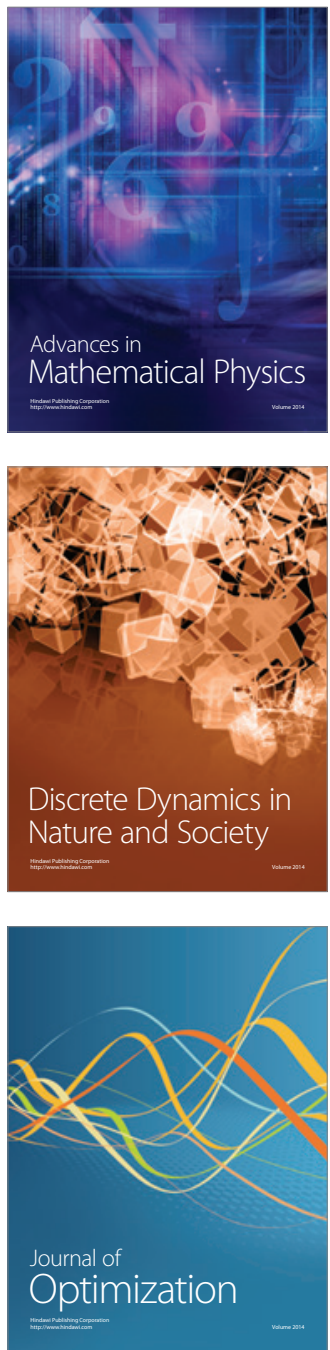